\title{
Collision Avoidance Control - Accurate in Narrow Water Case Study: in West Line Tanjung Perak Surabaya, Indonesia
}

\author{
Aulia Siti Aisjah",a,*, Agoes A. Masroeri' ${ }^{2, b}$ \\ ${ }^{1}$ Department of Physics Engineering, Institut teknologi Sepuluh Nopember Surabaya, Indonesia \\ ${ }^{2}$ Department of Marine Engineering, Institut Teknologi Sepuluh Nopember Surabaya, Indonesia \\ a.auliasa@ep.its.ac.id; auliasa20@gmail.com,b.masroeri@its.ac.id \\ *corresponding author
}

Keywords: Collision Avoidance; Fuzzy; COLREGS; DCPA; TCPA; Control; AIS

Abstract: The study of an automatic control system to avoid collisions between ships has been done through the design of an autopilot system. The algorithms of control based on fuzzy and applicable of COLREGS rules. This study was conducted in numerical computer simulation in variety of control fuzzy methods. Fuzzy logic system works based on AIS data, and the output system is the speed and direction of the vessel that is capable of avoiding collisions with other vessels and foreign objects. A case study was conducted on the western line of Tanjung Perak Surabaya, Indonesia. The result of the avoidancecollision system shows that the accurate increase of the distance and the different heading between the vessels is precisely generated by the DCPA-TCPA inputs of fuzzy control.

\section{Introduction}

The ship accident in some countries including Indonesia from 2010 to 2016, shows of 75-96\% cause by human error, and $32.4 \%$ is a ship collision. [1], [2], [3]. This conditions require a security system for sea traffic in Indonesian waterways, particularly on the narrow channel. The one of strategies for overcome it is applying technology to avoid collisions. The technology is needed for every ship in its cruise line, and also to avoid collisions between ships when crossing with by other vessels.

A strategy for improving safety of sea transport has been undertaken in several countries, and many researchers have studied about the methods, and its application to collision avoidance.[4] Anti-collision systems have been proposed by previous researchers, using conventional control systems, fuzzy logic control and decision systems based on artificial neural networks [2], [5], [6].

The distance at closest point of approach (DCPA), and time to closest point of approach (TCPA) are two variables that can be used to determine the probability of a ship collision. The AIS system was able to provide information on the position, speed, direction of ship, so it can be used to calculate of DCPA and TCPA. DCPA and TCPA have been successfully used to design ship anticollision systems.[7]

A control module has been designed for various purposes, i.e. course keeping, course changing, and collision avoidance modes. The control module was developed to obtain the best control response performance, so it can be used to support the autopilot in free and restricted waters. The 
modes of control in the module were developed based on the regulation of International Regulations for Preventing Collision at Sea-COLREGS [3].

\section{Method}

The method of the research in steps as follows, i.e. (1) Calculate the DCPA and TCPA as inputs of control, (2) Modelling of Ship Actuators, (3) Modelling of ship Dynamics, (4) design of Fuzzy Logic Control, (5) Simulation system control in the certain line.

The control system for anti-ship collision, shows in diagram block system in Figure 1 below. There are two scenarios in the anti-collision control system: first with no information from AIS, and second with information from AIS. The block diagram shows a scalar of the system's work, both with and without AIS. The switch scenario is an AIS ON-OFF function.

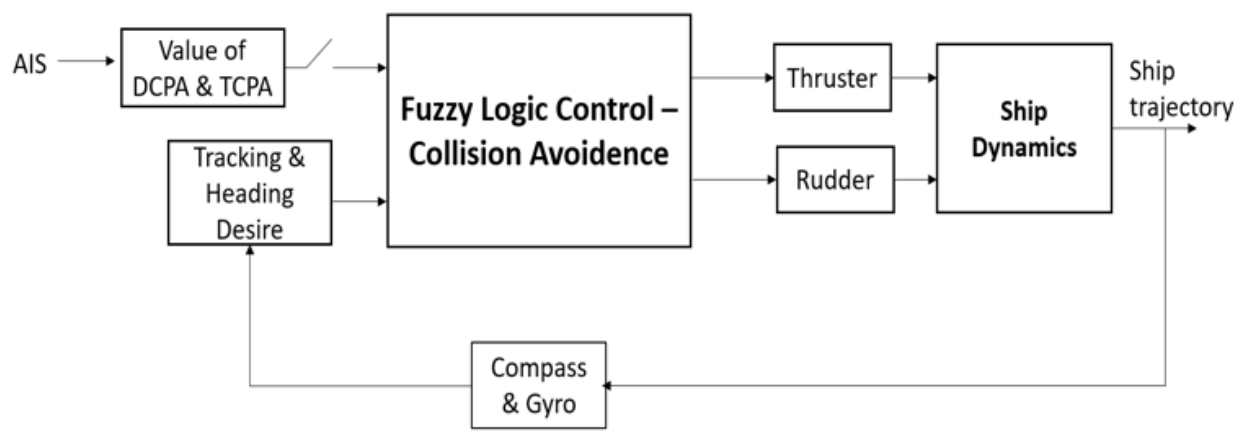

Figure 1: Block diagram of Fuzzy Logic Control - for Collision Avoidance

The control system will work with two inputs, from AIS and from the heading desired as set point. The heading desired was obtained from arc tag of ratio the difference of lateral position to the difference of longitudinal position. This difference was the error of actual ship's position to trajectory desired. The trajectory shown in Figure 3 below. The control system uses of fuzzy rules. The output of fuzzy controller was two signals, i.e. signal to drive the rudder and signal to drive the thruster. The movement of Thruster will cause the changes of ship speed, and displacement of rudder will cause the changes of ship heading.

\subsection{Calculate of DCPA and TCPA}

The Distance at Closest Point of Approach (DCPA) and Time to the Closest Point of Approach (TCPA) were two variables that indicate the probability of collision two vessels in the closest area.

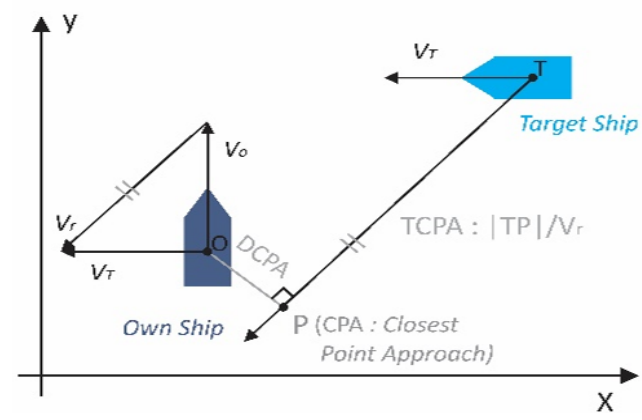

Figure 2: The DCPS and TCPA [8] 
The DCPA and TCPA were calculated from information of AIS from own ships and other ship (foreign ships). AIS on both vessels will provide static and dynamic in the certain period as it types.

\subsection{Modelling of Actuator}

The actuators used of two, i.e. thruster and rudder. Modeling of rudder dynamics used model approach of Van Amorengen. There is a rudder limiter and rate limiter in certain ranges. The range of rudder limiter is between $-35^{\circ}$ to $35^{\circ}$, and the rudder rate limiter is between $-7^{\circ} / \mathrm{sec}$ to $7^{\circ} / \mathrm{sec}$. The thruster models use the first order system [9].

\subsection{Modelling of Ship Dynamics}

This study was conducted in computer simulation. The system is design as the block diagram in Figure 1 above. One of the most important stages in controller design is mathematical modeling of ship dynamics. Mathematical modeling of ship dynamics use second order of Nomoto. The second order of Nomoto models is expressed in Equation 1 below [10].

$$
\frac{\psi}{\delta_{R}}(s)=\frac{K_{R}\left(1+T_{3} s\right)}{s\left(1+T_{1} s\right)\left(1+T_{2} s\right)}
$$

where the parameters in (1) above are obtained from the inertial matrix coefficient of $\mathrm{M}$, the damping matrix of $\mathrm{D}$ and the moment-force vector of $\mathrm{b}$, from the following matrix equation [11].

$$
M \dot{v}+N\left(v_{0}\right) v=b \delta_{R} \mathrm{M} \dot{v}+\mathrm{N}\left(\mathrm{u}_{0}\right) \mathrm{v}=\mathrm{b} \delta_{\mathrm{R}}
$$

\subsection{Design of Fuzzy Logic Control (FLC)}

FLC is one of expert control system that produces a control signals. FLC consists of 3 units, that is: fuzzifier, inference system, and defuzzifier. In the collision-avoidance system, designed for input variables are: (1) error of yaw angle, (2) yaw rate, (3) value of DCPA and TCPA. The membership function of error yaw is trapezoidal forms. The interval of function is between $-35^{\circ}$ to $35^{\circ}$, and consists of 7 (seven) membership, there are: NB-Negative Big, NM-Negative Medium, NSNegative Small, ZE-Zero, PS-Positive Small, PM-Positive Medium, PB-Positive Big. The second input variable is yaw rate, is expressed in the 7 (seven) trapezoid membership function in intervals of $-6^{\circ} /$ sec. to $6^{\circ} / \mathrm{sec}$.

The type of fuzzy logic in this study uses two types, namely Sugeno Takagi (ST) and Mamdani (M) types. Both types were tested on simulation, and then analyzed the difference of accuracy of output system. The Fuzzy-ST works on the fuzzy input variables and generates an output in numerical value. The fuzzy-M control works in numerical input variables and the output is in numerical values [13]. The SLF mechanism to generate of output through the stages: (1) change the numerical values into fuzzy values, (2) choose the appropriate rule according to the input variable values, (3) produce the output by changing the fuzzy to numerical value. Figure 4 below is an illustration of the surface viewer of the Mamdani fuzzy logic system for signal command rudder, with 49 rules. 
$\mathrm{R} 1$ : If $\mathrm{e}$ is NB and $\mathrm{r}$ is NB Then Ur is ZE

...

R8: If e is NB and $r$ is $P B$ Then $\mathrm{Ur}$ is $\mathrm{PB}$

R49: If e is PB and $r$ is PB Then Ur is ZE

The output value of rudder signal is increase as increasing the input of error yaw and yaw rate. The symmetrical pattern of surface in negative and positive values of yaw and yaw rate. This mechanism is easier applicable in the real.

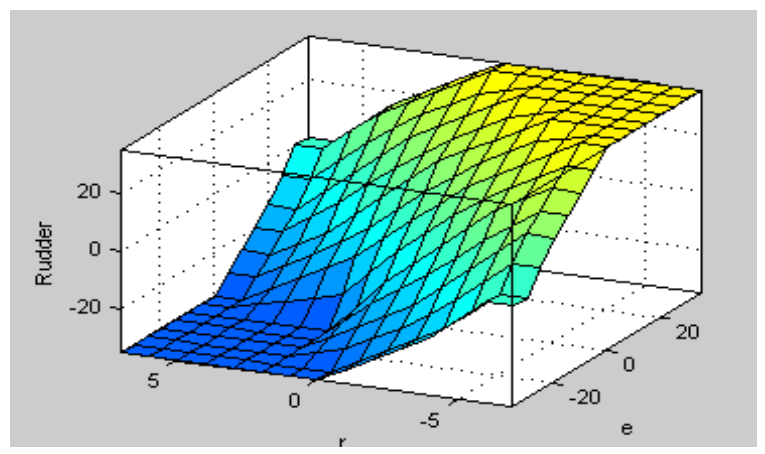

Fig. 3 Surface viewer of fuzzy logic control for rudder

The number of control rules for thruster system is 9. This rule is action of controller to change the speed of the ship. For example, if another ship moves to close from the right (starboard), the own ship must immediately make changes in speed and / or turnaround. Figure 4 shows the surface viewer for the thruster control system. In the below figures is rule / correlation of output signal control of thruster. The output of control signal Ut is low when the DCPA and TCPA are in small value, and increase as increasing the DCPA.

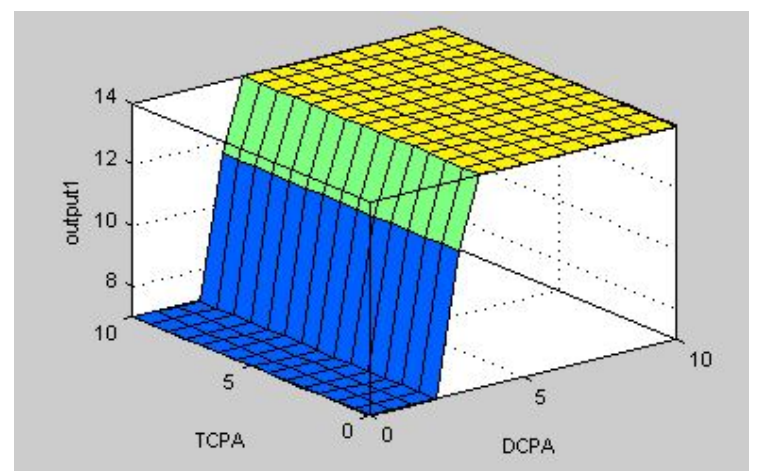

Figure 4: Surface viewer of logic system fuzzy for controlling the rudder.

\section{R1: If DCPA is Small and TCPA is Small Then Ut is Slow \\ R9: If DCPA is Big and TCPA is Big Then Ut is Neutral}

Whereas the fuzzy-ST have rules in the below statement, 


$$
\begin{aligned}
& \mathrm{R} 1: \text { If } \mathrm{e} \text { is } \mathrm{PB} \text { and } \mathrm{r} \text { is NB Then } \mathrm{Ur}^{1}=\mathrm{c}_{0}{ }^{1}+\mathrm{c}_{1}{ }^{1} \mathrm{e}+\mathrm{c}_{2}{ }^{1} \mathrm{r} \\
& \text { R8: If e is NB and } \mathrm{r} \text { is PB Then } \mathrm{Ur}^{8}=\mathrm{c}_{0}^{8}+\mathrm{c}_{1}{ }^{8} \mathrm{e}+\mathrm{c}_{2}{ }^{8} \mathrm{r} \\
& \text { 4: If } \mathrm{e} \text { is PB and } \mathrm{r} \text { is PB Then } \mathrm{Ur}^{49}=\mathrm{c}_{0}{ }^{49}+\mathrm{c}_{1}{ }^{49} \mathrm{e}+\mathrm{c}_{2}{ }^{49} \mathrm{r}
\end{aligned}
$$

where Ur is the output signal control of command thruster, $\mathrm{c} 0, \mathrm{c} 1$, and $\mathrm{c} 2$ are constants whose value is obtained from the least square method in the best relation of magnitude of $u$ by the magnitude of yaw (e) and yaw rate (r) [14].

\subsection{Simulation Control of Western Line Tanjung Perak Port - Surabaya}

Testing of controller use of a case study in certain trajectory. The study of Tanjung Perak Surabaya western line, The trajectory of line is illustrated in capture of google map in Figure 5 (left) below. The position in along line is marked by Latitude and Longitude coordinates. In this study position is 12 buoys were located at the line. The initial line is from the port entry point, i.e. Karang Jamuang. The destination is in the parking position (Naval Base). The trajectory of ship is along this line for arrival or departure of Tanjung perak port.

\section{Result and Analysis}

The simulation test is done by open and close loop system. In open loop test by providing the set point of heading of $20^{\circ}$ and $30^{\circ}$. The close loop test is performed in the course keeping and course changing. The object of own ship is a commercial ship with specifications: length of ship-Lpp = $92.3 \mathrm{~m}$, breadth-B $=16.5 \mathrm{~m}$, depth $\mathrm{T}=7.8 \mathrm{~m}$, Block coefficient $=0.48$; service speed $=4.63 \mathrm{~m} / \mathrm{s}$; displacement $=5245$ tons. The test is performed in accordance to IMO standard, in set point yaw of $20^{\circ}$ and $30^{\circ}$. The test results show the performance of the control system response in the time domain is appropriate to the IMO criteria.

The second test is running of trajectory controller of own ship to meet the desired trajectory along the Tanjung Perak Western line. Trajectory is made in the form of a linear equation relationship between one point and another adjacent point. This line as a basis for calculating the set point of heading. Changes in heading settings adjusted by error of actual position to the desired position. The difference between desired and actual as arc tg of heading angle. The trajectory test is shown in Figure 5 on the right. It is seen in the figure that the ship trajectory is able to follow desired trajectories.

The third simulation is done by trying the own ship movement from Naval Base (position 1) to Karang Jamuang (position 12). At position between 7-8 there is a foreign ship will across from the starboard direction. The simulation is done for 3 (three) scenarios. The first scenario, without variable of TCPA and DCPA, and the FLC is Fuzzy Sugeno Takagi (ST) control system. The second scenario is the same with the first scenario but use of FLC is Fuzzy Mamdani (M). The third scenario using the TCPA input variable, DCPA integrated with FLC of Fuzzy Mamdani. Figure 6 below shows the movement of the ship as result of simulation. The rudder able to work to bring the moving of ship as COLREG regulation. 


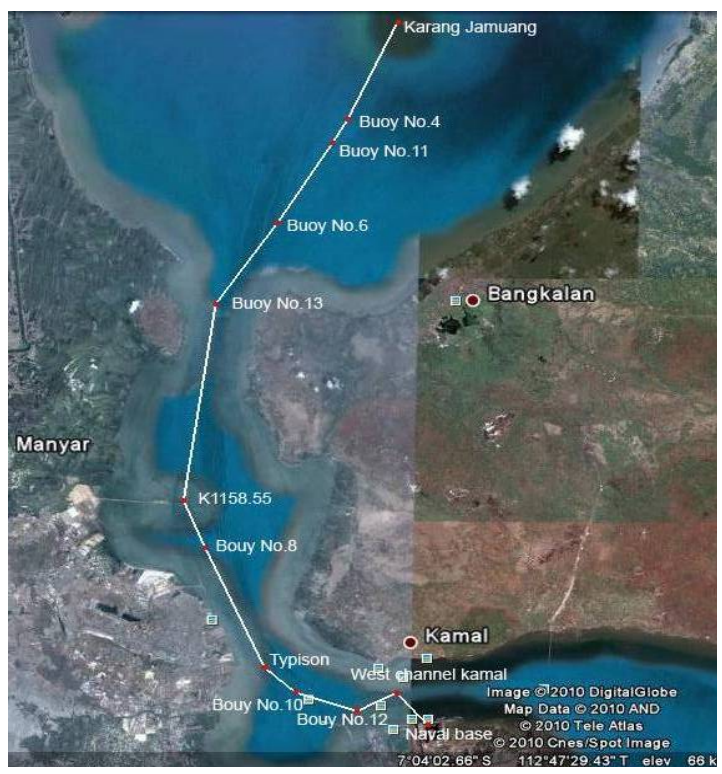

Figure 5: The western line of Tanjung Perak Surabaya (left), the result of trajectory control (right).

The magnitude of error position when the ship crossing of each position is shown in Table 1 below. It is seen the TCPA-DCPA input of FLC gives the smallest errors along the length of the position. The largest error position at point of 7-8 is the result of Fuzzy Mamdani control system. The error is $50.2 \mathrm{~m}$ at position 7 , and $85.1 \mathrm{~m}$ at position 8 .

The use of DCPA and TCPA is capable of causing the ship to move to avoid collision with other vessels, in which in head to head. The result of the control action due to collision avoidance shows the ability of the ship's rudder control to move the ship in the expected trajectory.
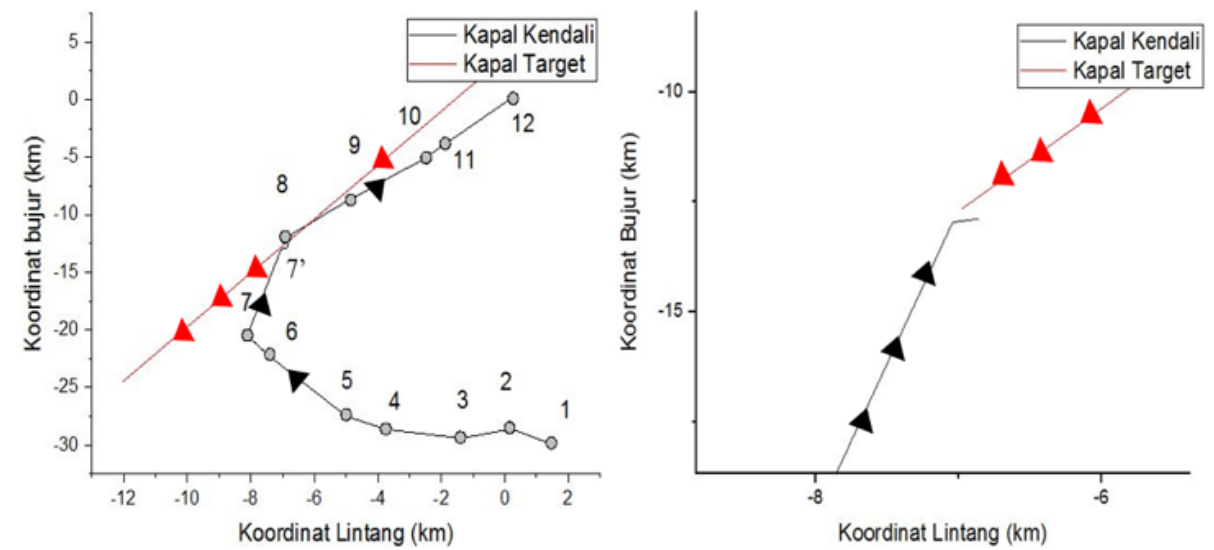

Figure 6: The movement of the ship to avoid collisions with other vessels in positions 7-8: (a) the movement of own ship from Naval Base, and foreign ships move from Karang Jamuang, (b) The zoom of two ships movement (own ship and strange ship). 
Table 1: The Error Position in 3 Scenario of Controller

\begin{tabular}{|c|c|c|c|}
\hline \multirow{2}{*}{ Buoy (Position Number) } & \multicolumn{3}{|c|}{ Error position (m) } \\
\cline { 2 - 4 } & $\begin{array}{c}\text { Fuzzy - Sugeno } \\
\text { Takagi }\end{array}$ & $\begin{array}{c}\text { Fuzzy } \\
\text { Mamdani }\end{array}$ & $\begin{array}{c}\text { Fuzzy Mamdani }+ \\
\text { TCPA DCPA }\end{array}$ \\
\hline Naval Base (1) & 20.2 & 20.1 & 0.0 \\
\hline West Channel Kamal (2) & 14.4 & 14.1 & 7.04 \\
\hline Bouy No.12 (3) & 15.9 & 98 & 5.03 \\
\hline Bouy No.10 (4) & 27.1 & 26.4 & 3.02 \\
\hline Typison (5) & 13.7 & 13.2 & 10.06 \\
\hline Bouy No.8(6) & 27 & 15.3 & 12.07 \\
\hline K1158.55(7) & 54.4 & 50.2 & 14.08 \\
\hline Bouy No.13(8) & 28.3 & 85.1 & 17.10 \\
\hline Bouy No.6(9) & 19.1 & 18.2 & 12.07 \\
\hline Bouy No.11 (10) & 17.6 & 18.1 & 11.07 \\
\hline Bouy No.4 (11) & 33.2 & 26.4 & 4.02 \\
\hline Karang Jamuang (12) & 6 & 6 & 1.00 \\
\hline
\end{tabular}

\section{Result \& Discussions}

\subsection{Fuel Consumption}

Fuel consumption is estimated using the logical structure described in section 3.1 and presented in Table I below. As the pure fuel-oil based system used in the first case, no boil-off gas is consumed for power. The boil-off gas generated is re-liquefied to make the total energy of LNG remains stable until reaching the port of destination. Figure 8 shows the total voyage fuel consumption for all three exporting countries considered. From all three scenarios, it is evident that the fuel consumption from the US is the highest one due to the greater number of sailing days compared to Australia and Qatar.

Table 1: Fuel Oil Consumption Calculation

\begin{tabular}{|l|c|c|c|c|}
\hline \multicolumn{1}{|c|}{ Components } & Australia & Qatar & US & unit \\
\hline Fuel consumption (laden) & 141.11 & 141.11 & 141.11 & MT /day \\
\hline & 533.90 & $1,295.04$ & $3,984.26$ & MT \\
\hline Fuel consumption (ballast) & 138.99 & 138.99 & 138.99 & $\mathrm{MT} /$ day \\
\hline & 525.88 & $1,275.59$ & $3,924.40$ & $\mathrm{MT}$ \\
\hline In Port (cargo operation) & 50.00 & 50.00 & 50.00 & $\mathrm{MT}$ \\
\hline Total fuel consumption & $1,109.78$ & $2,620.63$ & $7,958.66$ & $\mathrm{MT} /$ voyage \\
\hline Fuel price & 581.42 & 581.42 & 581.42 & USD / tonne \\
\hline Fuel oil cost & $\mathbf{6 4 5 , 2 4 8 . 6 1}$ & $\mathbf{1 , 4 9 4 , 6 1 5 . 8 1}$ & $\mathbf{4 , 5 9 8 , 2 5 0 . 4 4}$ & USD / voyage \\
\hline & $\mathbf{0 . 2 4}$ & $\mathbf{0 . 5 5}$ & $\mathbf{1 . 6 9}$ & USD / MMBtu \\
\hline
\end{tabular}

For the second scenario, the total energy required by the LNG carrier is met by the boil-off gas generated in laden and ballast condition. The total energy needed from three different countries is 
shown in Table II. Based on the calculation of boil-off gas generated in Table III, the total energy required from Australia, Qatar, and the US can be covered by the BOG only. In other words, the pure-gas burning system is feasible because the vessel does not need fuel oil to support the BOG in the burning system. Although there is no component of fuel oil cost, the total energy of LNG transferred to storage in the port destination will decrease.

Table 2: The Total Energy Required for LNG Carrier

\begin{tabular}{|c|c|c|c|c|}
\hline Components & Australia & Qatar & US & unit \\
\hline Total fuel consumption & $1,109.78$ & $2,620.63$ & $7,958.66$ & $\mathrm{MT} /$ voyage \\
\hline & $43,281,442$ & $102,204,578$ & $310,387,562$ & $\mathrm{MJ} /$ voyage \\
\hline & $\mathbf{4 1 , 0 2 3}$ & $\mathbf{9 6 , 8 7 1}$ & $\mathbf{2 9 4 , 1 9 1}$ & $\mathrm{MMBTu} /$ voyage \\
\hline
\end{tabular}

Table 3: Boil-Off Gas Generated

\begin{tabular}{|l|l|l|l|l|}
\hline Components & Australia & Qatar & US & unit \\
\hline Boil off rate (laden) & $0.15 \%$ & $0.15 \%$ & $0.15 \%$ & $\mathrm{~m}$ / day \\
\hline & 1,419 & 3,442 & 10,588 & $\mathrm{~m} 3$ / voyage \\
\hline & 30,931 & 75,026 & 230,822 & $\mathrm{MMBTu} /$ voyage \\
\hline Boil off rate (ballast) & $0.06 \%$ & $0.06 \%$ & $0.06 \%$ & $\mathrm{~m} 3 /$ day \\
\hline & 568 & 1,377 & 4,235 & $\mathrm{~m} 3 /$ voyage \\
\hline & 12,372 & 30,011 & 92,329 & $\mathrm{MMBtu} /$ voyage \\
\hline Total & $\mathbf{1 , 9 8 6}$ & $\mathbf{4 , 8 1 8}$ & $\mathbf{1 4 , 8 2 3}$ & $\mathbf{m 3} /$ voyage \\
\hline & $\mathbf{4 3 , 3 0 3}$ & $\mathbf{1 0 5 , 0 3 7}$ & $\mathbf{3 2 3 , 1 5 1}$ & MMBtu / voyage \\
\hline
\end{tabular}

\subsection{Shipping Cost}

The cost to ship one MMBtu of liquefied natural gas from three different countries is given in Table IV. Shipping costs range from 0.43 to 3.16 USD / MMBtu depending on the LNG sources. The shipping cost from the US is the highest one with 31.16 USD / MMBtu because of the longer distance than Australia and Qatar. On the other hand, shipping cost from Australia and Qatar are 0.43 and 1.03 USD / MMBtu respectively. The total shipping cost incurred is still likely to increase because the regasification cost component has not been included in the calculation model.

Table 4: Shipping Cost Calculation

\begin{tabular}{|l|c|c|c|c|}
\hline \multicolumn{1}{|c|}{ Cost Components } & Australia & Qatar & US & unit \\
\hline Port and passage fees & 0.04 & 0.11 & 0.33 & USD / MMBtu \\
\hline LNG carrier hire cost & 0.15 & 0.37 & 1.14 & USD / MMBtu \\
\hline Fuel oil cost & 0.24 & 0.55 & 1.69 & USD / MMBtu \\
\hline Total shipping cost & $\mathbf{0 . 4 3}$ & $\mathbf{1 . 0 3}$ & $\mathbf{3 . 1 6}$ & USD / MMBtu \\
\hline
\end{tabular}

Fuel oil and LNG carrier hire cost have a higher impact on the total shipping cost compared to port and passage fees. The fuel oil and LNG carrier hire cost themselves are related to the total 
sailing days. If the sailing duration from a country is higher than another country, the cost of vessel hire will be higher because in the case given, the vessel is chartered based on time charter.

\section{Conclusions}

An anti-collision was designed use of integrated of FLC and DCPA and TCPA. From the results of the ship simulation shows FLC as collision avoidance controller able to move the own to change direction and to change the speed when will crossing with other strange ship. The conclusions are as follows:

- FLC Sugeno Takagi give better performance than Fuzzy Mamdani.

- DCPA and TCPA as variables input of FLC give more accurate of error trajectory.

\section{References}

[1] Komite Nasional Keselamatan Transportasi, “Data Investigasi Kecelakaan Pelayaran Tahun 2010 - 2016," no. November. pp. 1-18, 2016.

[2] L. P. P. J. P. Carvalho and C. G. Soares, Bayesian Network based sequential collision avoidance action execution for an Ocean Navigational System, vol. 43, no. 20. IFAC, 2010.

[3] A. S. Aisjah, A. A. Masroeri, E. B. Djatmiko, and W. D. Aryawan, "M\&C (Monitoring and Control) System For Increasing Ais Capability In Sea Management Transportation," in SENTA 2008, 2009, no. September 2003.

[4] Marine Dept. HKSAR China, "The 10 International Symposium On Vessel Traffic Services," Hongkong, 2004.

[5] T. Praczyk, "Neurocomputing Neural anti-collision system for Autonomous Surface Vehicle," Neurocomputing, vol. 149, pp. 559-572, 2015.

[6] U. Simsir, M. Fatih, M. Bal, and U. B. C, "Decision support system for collision avoidance of vessels," Appl. Soft Comput., vol. 25, pp. 369378, 2014 .

[7] M. Tsou, "Multi-target collision avoidance route planning under an ECDIS framework," Ocean Eng., vol. 121, pp. 268-278, 2016.

[8] X. Wang, Z. Liu, and Y. Cai, "The ship maneuverability based collision avoidance dynamic support system in close-quarters situation," Ocean Eng., vol. 146, no. August, pp. 486-497, 2017.

[9] T. I. Fossen, Handbook Of Marine Craft Hydrodynamics And Marine Craft Hydrodynamics And. Norway: John Wiley \& Sons, 2011.

[10] T. I. Fossen, Marine Control Systems, Guidance, Navigation, and Control of Ships, Rigs and Underwater Vehicles. Tronheim, Norway, 2002.

[11] A. S. Aisjah, A. A. Masroeri, M. A. Efendi, E. B. Djatmiko, D. Ariyawan, and F. A. Iskandarianto, "Fuzzy Autopilot For Ship Tracking Optimizing In Karang Jamuang - TanjunG PERAK," in Seminar SENTA FTK 2010, 2010, pp. 1-11.

[12] T. I. Fossen, Guidance and Control of Ocean Vehicles - Thor I. Fossen.pdf, 1st ed. Trondheim: British Library, 1994.

[13] A. S. Aisjah, A. A. Masroeri, and R. Anitasari, "Collision Avoiandce By Design Fuzzy Logic Maneuvering," in SENTA 2010, 2010, pp. 1-9.

[14] S. Aisjah, Aulia S.; Masroeri, AA; Arifin, "Perancangan Sistem Kontrol Cerdas Pada Manuvering Kapal Untuk Menghindari Tabrakan Di Perairan Lepas," 2009. 